\title{
WHIGS AGAINST TORIES: THE DEVELOPMENT OF AMERICAN DRAMA
}

\author{
Violeta Janjatović, State University of Novi Pazar, \\ violetavesic@gmail.com
}

Original scientific paper

DOI: 10.31902/fll.32.2020.4

UDC: 821.111(73).09-2(091)

\begin{abstract}
The overwhelming sarcasm and the taunting satire are certainly the feelings that accompanied the American revolutionary period. Approaching both the struggle for independence and the American Revolution, it is discovered that the colonists' sense of laughing and ridiculousness became more pronounced and readier in recognizing the weakness of its enemy and presenting it to the world through the biting laughter of satires. Many satires of this character did not suddenly appear. Their appearance leads to a period many years before the outbreak of the War of Independence and the famous Bacon Rebellion in 1676. Nevertheless, what cannot be denied is that by the approach of 1776, dramatic creativity started its rapid development. Immediately after the first war blow, satires began to be published in nearly every newspaper in the American colonies.

American dramatists took an active part in the struggle for independence. At first, the potential, and later, an inevitable revolution made dramatists from the ranks of patriots and loyalists define themselves, their opponents, and the nature of the conflict itself in a way that remains intriguing and powerful over two hundred years later.
\end{abstract}

Keywords: drama, theater, Whigs, Tories, American Revolution

\section{Introduction}

William Dunlap, the father of American drama, defined the theater in 1832 as a powerful engine that should be put into the hands of people to transform the American nation (Dunlap 133). In order to understand the characteristics of this drama engine, it is necessary to analyze the forces that created it. This paper will examine the role of the theater and the dramatic activity in America during the Revolution, which, in the opinion of many researchers, established America's cultural identity.

One of the first and fundamental forms of colonial drama was a dialogue. Both patriots and loyalists remained truthful to this direct expression, which allowed the author to express and develop his arguments through a form that was easy to understand and, at the 
same time, funny. Despite their propaganda purpose and the tendency to rely on speakers rather than fully-developed characters, dialogues nevertheless provided some essential characterization and contained the basics of dramatic conflict (Richardson 28). The authors of the first dialogues might not have been sufficiently talented to overcome the constraints of this form. However, the dialogues were still extremely popular at that time both with the Whigs and the Tories.

\section{Divided attitudes}

Even though the outbreak of the American Revolution brought down the output of literary creations of the Tories and reduced it to some historical observations, they were still notable authors during the period of the revolutionary war. Nevertheless, in spite of sporadic dialogues or dramas, the Tories were less enthusiastic about engaging in literary activities than the Whigs. Their indecision can be explained in many ways. Many colonies, including New York, the future loyalist stronghold, showed divided attitudes towards drama and theater. Although the loyalists, following the British tradition and culture, visited theaters and were dedicated to them, that commitment did not lead to the strengthening of the dramatic genre. Even those loyalists who felt instant security and who had the opportunity to experiment with literary genres and types would decide to wait until the situation in the colonies was resolved. They considered neutrality as the best solution (Richardson 41).

\subsection{The loyalists}

The dialogues that came out of the pens of loyalists made more interesting propaganda work, although their quality among dramatic achievements is speculative, as in the case of patriotic dialogues. While the patriots used rhetorical arguments as primary weapons in their dialogues, the loyalists chose humor. Having doubted the boldness of those who believed that it was possible to dictate to the most powerful empire in the eighteenth century and to dismiss the social and political system, which, from their perspective, needed little change, the loyalists ridiculed the proponents of independence. They suggested that radical patriots wanted a government that was a little better than the rule of an angry mob.

In a Dialogue Debates at the Robin Hood Society in the City of New York on Monday Night of 19th of July, 1774, an anonymous author attacked the New York patriots whose subversive actions, in his own words, led to a crisis, not only of their colony but also of the entire continent. This dialogue continued the charade of the radical Whig 
club. Its front page was saying that the work was printed by the decision of the Robin Hood Society. Although it can be undoubtedly said that this dialogue was written to oppose the convention of the First Continental Congress in 1774 in Philadelphia, its author did not attack any single participant of it individually.

A far more entertaining dialogue is A Dialogue between a Southern Delegate and his Spouse on his Return from the Grand Continental Congress (Mary 27-39). This dialogue uses a widespread controversy to criticize political opponents and participants of the American Continental Congress. The dialogue between a henpecked husband and his talkative wife expresses a loyalist view on the dangers of patriotic politics against the English. It also stresses the necessity and importance of stability that does not go hand in hand with independence. The author of this dialogue wants to point out that the loyalty that a woman owes to her husband is the same as the one that colonists owe to the United Kingdom. In his opinion, the wife violated natural law and order in the same way as the patriots tried to take on a role, they had no right for. This dialogue shows more dramatic characteristics than others from the same period. However, they do not make it an excellent dramatic achievement. Attempting to replace the seriousness of a political problem or to identify it with a farcical act had to be condemned to failure. Although the author showed sympathy and liking towards the political attitudes of the wife, her characterization of a tomboy was not by the rules of the eighteenthcentury decorum. So it can be concluded that she was not worthy of being a true representative of the loyalist side. While she continued to accuse her husband until the end of the dialogue, he, on the other hand, dismissed her accusations as exaggerated and suspicious due to the theatrical style of her expression and the overstatement of literary sources in her ideas (Richardson 30-31).

The Americans Roused in a Cure for the Spleen or Amusement for a Winter's Evening is one of the best developed dramatic dialogues written by a loyalist, and it is attributed to Jonathan Sewell. The essential elements of this dialogue include the presentation of colonial society and political attitudes through seven characters. As is the case in other loyalist dialogues, these characters, as representatives of the loyalists, possess intelligence and reason. On the other hand, Paff and Graveairs, who are representatives of the patriots, are at least naive. A representative of the Tories responds systematically to patriots' complaints, which makes them soon give up their complaints addressed to the United Kingdom government. One of the characters from the Tories says, speaking of the colonists, that they drove them 
out of peace and happiness. Another one speaks of the benefits of America and the relationship they have with Great Britain and concludes that all Americans are pleased, and he wishes they realized it. This dialogue thus has more characteristics of a political debate than drama. The absence of the epilogue is an apparent lack, and it is a consequence of the conflict which characterizes every good drama. In this case, the dramatic form is primarily used to increase the readers' interest, while the apparent propaganda intent of this part is clear (Philbrick 6).

The Battle of Brooklyn is an anonymous Tory farce, published in 1776, soon after the Americans were defeated at Long Island (Philbrick 169-211). This work resembles in its form satirical pieces of Mercy Otis Warren. Taking as the central theme the siege of Washington by the British army led by General William Howe and his brother, Admiral Richard Howe, this piece ridicules the command of patriotic military forces. It attacks the cowardice, drunkenness, and incompetence of the American military forces. The author of the piece presents General George Washington as an evil tyrant and his people as horse thieves, drunks, and cowards. He uses a technique with which he wants to undermine the faith of the patriots in their leaders and to point out that their moral mistakes will lead to the final fall, which this piece presents at the end. In the first act, the readers are introduced to members of the patriotic army. Stirling, one of the protagonists and a general in the American army, is portrayed as a drunkard and a coward. Soon after his description, the author switches to the conversation of the two generals, who reveal that they hijacked horses from Long Island residents and that they used their offices to hide them temporarily. After that, a conversation between General Howe's wife Horatia and her maiden Betty about the defeat of George Washington is presented (Philbrick 190-192). In the last scene of the first act, Putnam, one of the leaders of the patriots, expresses the hope that the revolution will impose a puritanical theocracy on everyone and that it will personally serve him for seizing loyalists' possessions. The second act begins with a detailed description of the battle of Brooklyn, which the British win with the help of their friends, the Tories. It further describes the happiness of the Tories because they manage to avoid the slaughter and a renewal of their vows on the faithfulness to the king.

Discussing the opposition in attitudes between American Whigs and Tories Jason Shaffer in his work Performing Patriotism: National Identity in the Colonial and Revolutionary American Theater claims that "Colonial Tories in this period of heightened political 
tension had begun to endorse the perpetual union of Britain and the American colonies not according to a doctrine of passive obedience but out of what they perceived as a mutual appreciation of British constitutional freedom." Shaffer suggests that "this view diverged sharply from the position of colonial patriots who increasingly characterized America as the last bastion of English liberties" (98). Thomas Paine, the great supporter of freedom and independence, and, in his own words, "the citizen of the world," eagerly embraced that idea, and tried in his works to present the growth of the radical spirit among the colonists.

\subsection{The patriots}

In Paine's work A Dialogue between General Wolfe and General Gage in a Forest near Boston, the British hero of the French and Indian war attacks on Quebec criticizes General Gage for failing to understand that every British has the right to freedom guaranteed by eternal laws of nature. Accordingly, the Americans have all the right to oppose the King for violating their natural rights (Paine 1945a, 2:4749). Paine's obvious intention in this dialogue was to point to the deficiencies of the 1774 Quebec Law which banned the spread of colonies to the west by spreading the boundaries of Quebec to Ohio and Mississippi rivers and at the same time securing the Catholic environment of Protestant New England and the colonies in the Middle Atlantic. However, the words of his work nevertheless suggested the possibility of reconciliation.

In dialogues that followed the Lexington and Concord events, such as A Dialogue between the Ghost of General Montgomery and an American Delegate, Just Arrived from the Elysian Fields, and A Wood near Philadelphia (1776), there was a noticeable change in Paine's views. His hero in these dialogues is a fighter and a martyr for freedom and by publishing a story about him, Paine became no less significant fighter for independence and a prominent propagandist of the patriotic movement. Paine's choice of General Richard Montgomery as an American hero placed him after his death, at the time of the siege of Quebec in 1775, on the same level with General Wolfe, but pointing at a parallel between the French tyrant from the French-Indian War and the British tyrant of that period. In A Dialogue between the Ghost of General Montgomery and an American Delegate, Montgomery highlights the impossibility of reconciliation, and he makes a comparison between the Greeks and Romans of the ancient period and their struggle for freedom on the one hand, and the American colonists 
and their struggle for independence, on the other hand (Paine 1945b, 2:88-93).

Shaffer observes that the Dialogue was printed as "a pamphlet during the Continental Congress debates over declaring independence." He, therefore, argues that it can be read as a "script for pro-independence activists during these debates. The American delegate raises a variety of common objections to declaring independence (the great military power of Britain, the fear of unrestricted republicanism) only to be refuted by the ghost of Montgomery. Montgomery serves not only as a mouthpiece for Paine's pro-independence, republican arguments, but also as an uncanny inspiration, allowing Paine to appropriate Montgomery's authority as a martyr" (161). This dialogue, like many others that Paine wrote during the revolutionary period, aimed at identifying the courage, honor, and love of freedom that Paine admired, but also at presenting his opponents as cowards and oppressive and dishonest people (Vickers 56). Although these dialogues were a useful propaganda weapon, their dramatic possibilities were poorly exploited.

\subsection{Toward the moderation and tolerance}

As is the case with most revolutions, the American fight for independence showed a tendency to eradicate political differences and to transform the ideology of patriotism into a system of the common good. For that reason, political dramas implied absolute political compliance that was contrary to the ideas they conveyed. These contradictions were typical for all American authors of this period. In the meantime, while patriots were fighting for independence, a voice emerged that propagated not only the struggle for freedom but also warned Americans of the danger caused by opposing patriotism. The opposition to patriotism would eventually replace the tyrannical rule of the British by the rule of the loyalist forces of their compatriots, who showed much higher potential for destructiveness (Richardson 43). Robert Munford, with his dialogue The Patriots, from 1775, questions the loyalty to the country, examines the individuality of consciousness after the outbreak of the conflict, and advocates political patience (Munford 2:54-132). Munford gives his political commentary through a traditional romantic plot. In the first plot, Isabel, one of the protagonists, is determined not to get married, because she cannot love a man who does not know anything about the war, nor about Washington. In the second plot, George Worthy, who is in disguise, tries to seduce Melinda Heartfree through a fake wedding. When his plan is discovered, he rejects his evil intentions and wins Melinda's 
heart, and then reveals that she is a long-lost niece of Meanwell, one of the heroes of this drama. In the main plot, Trueman and Mira are finally married succeeding in overcoming Brazen's disapproval because Brazen, as a great advocate of patriotism and a leader of the patriots, feels that Trueman is a Tory. The intertwined characteristic elements of a romantic comedy and the speech on political and personal loyalty prove the necessity of tolerance in the period of crisis. Munford manages to personify these issues through two different groups - a group of self-named protectors of the common good and a group of their enemies (Baine 74). The first group consists of a local council in charge of security, whose main task is the expulsion of the Tories. Brazen is a typical member of this group. He is a patriot who does not even know the reasons why he is. However, if they are forgiven for not knowing the motives for being radical supporters of their group, what cannot be justified is the lack of political sophistication as well as intellectual breadth. The political naivety of the council is depicted through the vicious success of Tackabout, who condemns the government, abuses the king, and defames the parliament. Due to the already mentioned lack of sophistication, they are not able to discover that their ideas and methods are in conflict. Their ideal of revolution is something that is just a little better than a political agreement. One of them states that wise people should be excluded from politics because they always doubt and create divisions, and they are dangerous. They do not realize that what patriots seek is precisely that right to disagree on the individual and the collective. Apart from the main plot speaking about the outbreak of the revolution, mistrust, and hatred that American Tories felt for American Whigs, and vice versa, Munford's work is, first of all, notable because he does not take sides in it. Still, he emphasizes the importance and possibility of reaching an agreement. The main characters of this piece, Trueman and Meanwell, are the advocates of Munford's ideals of moderation and tolerance. At the end of the work, Meanwell declares that he hopes his fervor towards tyranny will not be shown as a fight against it, but as a service to the country against the enemy. He also declares that he will never emphasize his devotion to freedom by condemning an innocent man, only because he does not share his opinion on specific issues. This dialogue, in comparison to others from the same period, written by both the Tories and the Whigs, emphasizes reason against blind patriotism and insistence on the beginning of war operations or the complete rejection of the reasons for dissatisfaction and rebellion. 


\section{Theater in America during the Revolutionary War}

Many colonial Americans of the eighteenth century opposed a professional theater under the rule of the United Kingdom, citing the fact that it competed with the development of American mercantile companies. No monetary amount could allow theatrical patrons to buy American goods or services. In this situation, the theater was nothing but unwanted entertainment (Shaffer 2017, 19). It represented the political and social symbol of the repressive government of Great Britain. Heather Nathans in his study Early American Theatre from the Revolution to Thomas Jefferson. Into the Hands of the People claims that "prior to the war, resistance to theatrical activities had been largely a subject of debate between factions who objected to the theater for religious reasons, and elite groups, who supported the theater as a link with 'civilized' British culture." Nathans suggests that "to members of religious sects, such as the New England Puritans, the Pennsylvania Quakers, and the New York Presbyterians, the theater was a source of evil, its primary function was to teach seduction and revolt, and it "threatened to subvert their plans for establishing ideal society" (13). One of the reasons why puritans left the United Kingdom in the second half of the seventeenth century was the desire to escape the corrupt culture of restoration, of which the theater was an integral part. A few years earlier, more precisely, in 1649, when the parliamentary party took power in England and executed Charles I, one of its first decrees was the closing of all theaters in the country. When Charles II came to power in 1660, theaters were reopened and featured mostly comedies that were flattering the king. These were performances in which the main themes were witty sexual intrigues, which, in the opinion of the puritans, were very offensive. In the meantime, women became part of the theater, while until 1649, women's roles were played by men. This fact was the most significant offense for puritans. For this reason, they were pleased to observe the birth of the theater in the new country (Brown 2-3).

\subsection{From the London Company of Comedians to the American Company}

By 1750 , only a few inhabitants of American colonies could boast of the fact that they had watched a theater performance. At the beginning of 1752, the first professional actors sailed for America. Its official name was London Company of Comedians, led by the family of Lewis Hallam (Brown 2-3). They tried to open the first professional theater in America. Their desire was met with numerous obstacles. Namely, the colonies were inhabited by poor and uneducated people, 
who were under the influence of the priesthood and who were told that going to the theater was only the loss of valuable time (Stout 49$65)$. The lucky circumstance was that they first came to Virginia, which was least affected by the religious resistance to entertainment since its population was mostly of Anglican origin. Still, they did not get permission to work there at first. After some time and with the support of some influential citizens, they resubmitted their request to the Royal Governor for obtaining a work permit, and this time it was received. The Hallams slowly progressed, extending the influence of the theater from Virginia to New York, Pennsylvania, South Carolina, and other colonies. Their repertoire contained classic English drama of the eighteenth century. After the death of Lewis Hallam in 1755, David Douglas took over the management of the company. They changed their name to The American Company in 1763, and with this change, they chose the side of the Americans in the conflict with the British (Butsch 27). Apart from that, on all other issues, among which the most important was the selection of performances and the recruitment of actors, they remained a British acting company. In 1767, American Company became the first acting company to perform a piece by an American author. It was the play Prince of Parthia by Thomas Godfrey (Brown 4).

\subsection{Choosing sides}

The relations between Great Britain and its colonies slowly reached the boiling point in the early seventies of the eighteenth century. Plays inspired by the emotions of colonial Americans with the current political situation increasingly became a part of the theater repertoire. They were sometimes at the side of the British, and sometimes glorified the values of the colonists. A more regular part of the audience were those who shouted out loudly their views (Shaffer $2017,19)$. As the political situation in the colonies worsened, the theater, like other aspects of colonial life, was drawn into controversies created by the conflict between Great Britain and colonies. Some found it an opportunity to condemn the American Company for hiring British actors and violating American values in that way. They argued that the repertoire of British plays and their actors in the colonies were bringing precisely the ideas against which the representatives of the radical patriots fought the most. In a desire not to allow their ruin, the management decided to go to London in 1774 and to hire new actors. However, it was in 1774 that the Continental Congress was held in Philadelphia, where it was decided that every American was guaranteed the right to life, freedom, and property. However, at the 
same time, they were asked to support the development of American companies and to forget about every kind of entertainment that could interfere with their conflict with Great Britain (Ford 79). In October 1774, George Washington signed a decision according to which the Congress called for reduction and gradual suspension of publication of all works whose primary purpose was the entertainment of the population, which included dramatic pieces. Members of the American Company soon realized that they could not fight against the Congress decision, so they closed all the theaters and sailed back to Great Britain (Rankin). However, shortly after accepting this congressional proposal, Washington, who was himself a great fan of theaters, repented, and on April 15, 1778, in Valley Forge, he allowed the performance of one piece. He was probably prompted by the desire to provide some entertainment to soldiers after a long and cold war period. A few weeks after that, another piece was performed, celebrating the alliance between France and America, which was signed that same year in Paris (Fitzpatrick 199).

Despite the closing of theaters or limiting their work, the period of the revolutionary war recorded significant dramatic activity (Shaffer 2006, 1). Although the Continental Congress managed to ban the work of professional theaters until 1781, it did not have any influence over the British military forces, which controlled New York, Philadelphia, and Boston. Unlike the Americans, the British liked drama and theater much more, so they continued to nurture this tradition during the revolutionary period. A large number of British theater performances also encouraged American officers to allow performances for American military troops. Although this decision was unlawful because of the previous Congress decision, it strengthened the morale of American soldiers and made the Americans feel that it was possible to compete with the British in all fields. This also led to a significant increase in dramatic activity. It is believed that the influence of Great Britain, or more precisely British soldiers and their love for the theater, did not matter much during the revolution until the colonists themselves developed an awareness of the significance of the theater. Historians believe that there was a large number of colonists who were devoted to the crown of Great Britain, and many who were still undefined in those first years of the revolutionary war. So it can be said that in that early period, many did not mind strengthening the drama activity, and on the other hand, those who did not approve of this activity were not willing to speak out loudly about it (Catton 6).

While the British and the Americans measured their military strength, a large number of pieces was published that depicted 
passions on both sides. Heather Nathans argues that "while the goal of the British wartime theatricals may have been to convince the colonists that all was well, that was obviously far from truth, as the struggle between loyalist and patriot continued to play out in New York's social and political spheres" (43). In aesthetic terms, most of these dramas were not of high quality, but their main intention was propaganda. The authors of these works wanted to help one group of readers to confirm their attitudes, and the other one, which was still undecided, to take the right side. Among these pieces were many of those who were not written for performing at the theaters. According to Norman Philbrick, interested readers who could not afford to buy a pamphlet used the opportunity to gather at taverns and barbershops, where the printed editions of these pieces were available, completely free, and where they could discuss the latest political developments with like-minded people (9).

\subsection{Satire as a powerful patriotic weapon}

Most propaganda pieces were satirical. Considering that it was not very important to display the virtues of American officers, patriotic authors often dedicated their pieces to displaying the flaws of the British (Shaffer 2006, 4). The Blockheads or The Affrighted Officers is a farce attributed to Mercy Otis Warren, written in response to The Blockade of Boston, performed by British officers in Boston (Philbrick 135-169). This piece speaks about the British attempt to seize a fort at Dorchester from General George Washington's army, as well as about their cowardice during the retreat. The author addresses the British directly, and he criticizes them for their cowardice, but also because they were not consistent with the promises they had made to their supporters. In his study The Theatre in America during the Revolution, Jared Brown says that "American Tories are portrayed throughout the play as amazed and disgusted at the bahaviour of the British officers. Instead of fighting the Americans, one says, 'our generals...are confin'd within three months of garrison, writing and acting comedies'" (72-73). Among the leading figures, the identities of General Howe and General Burgoyne are revealed. Evidently, the author of this piece was mild to the American Tories. Instead of criticizing them, he presented them as people who were horrified and stunned by the behavior of British officers. While the first plot follows the British reaction to the siege and desperate attempts of the British to regain power, as well as their final withdrawal, the other one talks about one Tory family, and it follows their destiny. The most interesting part of this piece is when the author focuses on the remorse felt by the family members because 
of the loss of their country and friends. The author also uses a great deal of irony to deal with the decision of the wife and the mother to continue supporting the British to retain her status of a lady, and then her daughter's plan to marry the elderly Lord Doppler and make her dream come true by going to London (Teunissen 157). Brown also states that "the potential effectiveness of The Blockheads or The Affrighted Officers as a burlesque is undermined by its extreme dramatic clumsiness" (73). However, despite the dramatic insecurity, this work served the American soldiers, as well as all others who supported them, to laugh at the British account. This piece bears similarity with other pieces of that period in its plot and disdain for the enemy, but also in a shared value they possess, that is, to present the testimonies of the profound intolerance of that era.

The Fall of the British Tyranny is a piece attributed to John Leacock, which starts with an exciting and satirical dedication to British officers in America, primarily because of their habit of performing dramas during the war (Leacock 277-350). Describing their hobby, the author suggests that British soldiers are doing it for the sake of their entertainment, but also to mock Yankees, their hosts, at the same time. It was precisely this term, which they used, that was supposed to serve to remind all British soldiers how much they were privileged to have permission to watch performances, unlike American soldiers who could not. In this regard, the author of The Fall of the British Tyranny states further in the dedication that this tragicomedy is just for them and their entertainment (Leacock 286). This is undoubtedly the most ambitious propaganda work of the revolutionary period, as well as one of the best. The action takes place over a period spanning as long as three decades, and the events take place in England, Canada, Virginia, and Massachusetts. The combination of various elements: pathos, melodramas, satire, spectacles, and songs make the author's categorization of this piece as a tragicomedy too modest (Brown 7576). The story begins in London in the 1750s, where Lord Paramount reveals his character traits through a monologue saying he intends to become a dictator of the whole of Great Britain. To achieve this, he declares that he intends first to tax the inhabitants of America (Leacock 297). At that moment, he does not think about the consequences that this tax could cause. Namely, the taxation of America would create enemies from the colonists and lead to a civil war. This civil war would further weaken the United Kingdom because all the troops would go to America, and it would remain unprotected and targeted by foreign powers. Furthermore, the civil war would also impoverish America, which is one of their most valuable and wealthiest colonies, which 
would again directly affect the welfare of the empire. Paramount is not alone in his intent. He also gathers other corrupt individuals who intend to overcome the Americans with the help of colonies loyal to the crown. Judas, behind whose character one can recognize the identity of Governor Hutchinson, encourages Paramount's efforts and ridicules the colonists who hope to win the war against the great military force. In addition to satirizing American enemies, Leacock also aims at greeting friends of American colonists. As an example, the speech of Lord Wisdom can be mentioned, in which he complains about Paramount's plan. Together with his friends, Lord Justice and Lord Religion, he swears he will do everything in his power to restore unity and peace in America. He declares thus:

"I love the Americans, because they love liberty. Liberty flourishes in the wilds of America. I honour the plant, I revere the tree, and would cherish its branches. Let us, my friends, join hands with them, follow their example, and endeavour to support expiring liberty in Britain; whilst I have a tongue to speak, I will support her wherever found; while I have crutches to crawl with, I will try to find her out, and with the voice of an archangel will demand for a sacrifice to the nation those miscreants who have wickedly and wantonly been the ruin of their country. O Liberty! O my Country!" (Leacock 305)

After this speech, the place of action is moved to Boston, where the battle continues. British soldiers are shown at their military camp while shaking with fear because of the danger. As a result of that fear, they soon begin to argue because the successes of the American army disrupt their plans. In the following scene, Lord Boston, behind whose name the identity of General Gage is discerned, addresses with contempt to Mr. Caper, i.e., Burgoyne, because he brings to America a dance teacher and a violinist (Leacock 337). With this scene, Leacock wants once again to laugh at the British and their officers, who, despite the seriousness imposed by the war situation, do not forget, or do not want to forget about the comfortable life they lived back in Great Britain. They try hard to take a part of that life with them even to the battlefield. The last act begins with the admiration of General Washington, Lee, and Putnam for the bravery of the Continental Army, immediately after the victory at Ticonderoga. Their enthusiasm is somewhat distorted by the news of General Montgomery's death in Quebec, but they decide to avenge his death and triumph in the war (Leacock 349). This piece also records dramatic weaknesses. The characters are reduced to caricatures of good and evil, and some more complex arguments are limited to those simple. Perhaps it can be 
concluded that such passionate controversy does not allow for different content. The scope of the work is too large to achieve efficiency, so there is no lingering over individuals or groups of main characters. According to Montrose Moses (Moses 281), the piece was performed in 1776, while Dallett claims that it was performed much before it was published (Dallet 467).

In the group of the best drama pieces of this period are The Battle of Bunker-Hill (1776) and The Death of General Montgomery (1777), written by Hugh Henry Brackenridge. Brackenridge, along with James Madison and Philip Freneau, was the founder of the American Society of Whigs in 1769. At the time of writing The Battle of BunkerHill, Brackenridge was a teacher at the Somerset Academy in Maryland, and shortly afterward, its director (Quinn 50). He wrote this piece for the students of the Academy, and he dedicated it to the brave American soldiers who participated in this battle. Although The Battle of Bunker-Hill tries to demonstrate the moral superiority of the Americans, Brackenridge in this piece treats the British with a certain degree of dignity (Brackenridge 1964, 233-276). Behind the names of the characters, the identities of American officers, Warren, Putnam and Gardiner, and the British, Gage, Howe, Burgoyne, and Clinton, are discerned. At the beginning of the drama, American soldiers prepare to attack the Bunker-Hill. At the same time, on the other side of the battlefield, the British are amazed that their great army cannot win such a small American (Brackenridge 1964, 251). Most of the piece speaks about the course of the battle, which was ultimately ended with the victory of the British army. Nevertheless, despite that outcome, it should be noted that the British turned out to be defeated, because they ended a conflict with one thousand fifty-four dead and wounded people, as opposed to five hundred Americans (Lancaster, Ketchum 109). This piece was probably challenging to perform, taking into account that it was written for students. In terms of structure, the fifth act seems to be significantly longer than the four previous ones, because it has ten scenes. The instruction for the stage performance at the beginning of the third act, according to which a gardener enters with seven hundred people, clearly indicates that Brackenridge was more focused on the accuracy of historical data than on the possibility for performance of the drama (Brackenridge 1964, 254). Although this piece has flaws in terms of the structure which does not have a certain degree of sophistication necessary for a good drama, it is nevertheless a powerful propaganda piece (Shaffer 2006, 14).

The Death of General Montgomery also speaks about the defeat of American military forces and the necessity of Americans to 
regroup and triumph at the end (Brackenridge 1976, 211-265). While in the previous piece, the British are portrayed as people who know they should respect the goals of the inhabitants of the American colonies, in this piece, Guy Carleton, who was the commander in chief of Québec and the Governor of Canada, is portrayed as a treacherous and a beastlike being. After his soldiers beat the Americans at Quebec and kill General Montgomery, Guy Carleton exhibits Montgomery's body to the rebels and asks them to surrender. He threatens them if they do not do it, he will feed the vultures and the poultry with the body of the dead general. When they finally agree to surrender, Carleton violates the given word and hands over the three captured Americans to angry Indians. When subsequently commenting on the ferocity of the pictures he presented in this piece, Brackenridge said that his description of Carleton's behavior was realistic and that he reflected the practice of British officers in general, as cruel, immoral and fickle people. In this respect, Brackenridge's statement highlights the superiority of American characters over the British. He also points out that the Americans are militarily ready and capable of defeating the British, and that they must win, because the enemy has proven to be inhuman and fickle. Although the characterization of American characters is not at the same level as the characterization of the British, the text recognizes the author's conviction about them as models of value and courage (Shaffer 2006, 1). This drama lacks dynamics, and dialogues are used for long monologues instead of the development of the action. Nevertheless, what undoubtedly leads the action and makes this work particularly noteworthy is the author's faith in the bright fate of his country (Brown 82-83).

One of the last significant dramatic works written during the revolutionary war is The Motley Assembly, anonymously published, but later attributed to Mercy Otis Warren (The Motley Assembly 347-358). This drama presents a satire against those Bostonians who were craving for a cheerful and elegant life and time before the British occupied the city, and before the American supremacy in the war began to affect their active social life. Mr. Turncoat is a typical representative of this group of people. He and his friends make every effort to ignore the existence of the war. Captain Careless, an American marine, is opposed to them, fearing that their behavior could undermine the success the Americans have achieved in the war so far. Addressing his enemies, he points out the danger of their association when he says: "I am ashamed of the conduct of some of this town, who profess themselves Whigs. They are not barely doubtful, but in my opinion the most dangerous characters among you" (The Motley 
Assembly 352). There is no real action in this drama, but there is only a series of dialogues. The value of the work is seen only in describing the anger of the American patriots because of their compatriots, the lovers of luxury life.

It is not particularly challenging to find the shortcomings of many dramatic pieces created during the revolutionary period. They have both dramatic and literary flaws. However, these are the first attempts of the original American drama, as well as the opportunity for American authors to explore American values in their voices, fighting for American goals. For this reason, these pieces are of great historical significance.

\section{Conclusion}

American drama is a literary genre that may have been mostly inspired by propaganda and republican spirit. The drama of the early republic was firmly tied to the sphere of citizenship. It retained its commitment to the common good, long after poetry and prose replaced the general good with some more personal goals. In this way, drama and theater remained closest to people. (Gilmore 573).

American drama pieces released during the revolutionary war form a large part of the revolutionary literature. These dramas represent the social, cultural, and political world simplified by the aesthetics of the revolution, and this inextricable connection between them requires good knowledge and understanding of each one individually, when interpreting these literary works. If these works were exclusively appreciated as dramatic achievements and evaluated by dramatic norms, this would then signify a sure disappointment concerning the dramatic legacy of the eighteenth century. However, these dramas are of great historical significance, as they transmit and revive the passions, motives, and mood of that period, using a realistic approach, with which works of other genres could not boast of (Tyler $2: 188)$. Considering the low price of pamphlets and daily newspapers in which they were published, many people read those pieces (Meserve 60). According to Ralph Borden Culp, about 128 pieces, whose author was not Shakespeare, were shown in the American colonies between 1758 and 1767. A large number of those pieces were inspired by the Whigs and the Tories, and their ideologies (Culp 79-86). Taking into account the fact that so many dramatic pieces were used for propaganda purposes, it can rightly be said that they were mostly responsible for shaping the view of the colonists in the upcoming struggle for independence. 


\section{BIBLIOGRAPHY}

Baine, Rodney M. and Robert Munford. America's First Comic Dramatist. Athens: U of Georgia P, 1967.

Brackenridge, Hugh H. "The Death of General Montgomery in Storming the City Of Quebec, 1777." Trumpets Sounding: Propaganda Plays of the American Revolution. Ed. Norman Philbrick. New York: Arno P, 1976. 211-265.

Brackenridge, Hugh H. "The Battle of Bunker-Hill." Representative Plays by American Playwrights 1765-1819. Ed. Moses J. Montrose. New York: Benjamin Bloom, 1964. 277-350.

Brown, Jared. The Theatre in America during the Revolution. Cambridge: Cambridge U P, 1995.

Butsch, Richard. The Making Of American Audiences: From Stage to Television, 1750-1990. Cambridge: Cambridge U P, 2000.

Culp, Ralph B. "Drama-and-Theater in the American Revolution." Speech Monographs 32.1 (1965): 79-86.

Dallett, Francis J. Jr. "John Leacock and the Fall of British Tyranny." Pennsylvania Magazine of History and Biography 78 (1954): 456-475.

Dunlap, William. History of the American Theatre. Vol. I. New York: Burt Franklin, 1963.

Fitzpatrick, John C. The Diaries of George Washington 1748-1799. Vol. II (1771-1785). Boston and New York: Houghton Mifflin, 1925.

Ford, Worthington C. et. al. Journal of the Continental Congress, 17741789. Vols. I, II. Washington: Library of Congress, 1904-1905.

Gilmore, Michael T. "The Literature of the Revolutionary and Early National Periods."Ed. Sacvan Bercovitch. The Cambridge History of American Literature, Vol. I, 1590-1820. Cambridge: Cambridge U P, 1994. 539-676.

Mary, V. V. “A Dialogue between a Southern Delegate and his Spouse on his Return from the Grand Continental Congress: A Fragment, Inscribed to the Married Ladies of America, by Their Most Sincere and Affectionate Friend and Servant." Ed. Norman Philbrick. Trumpets Sounding: Propaganda Plays of the American Revolution. New York: Arno P, 1976. 27-39.

Ketchum, Richard and Bruce Lancaster, eds. The American Heritage Book of the Revolution. New York: American Heritage Publishing Company, 1971.

Leacock, John. "The Fall of the British Tyranny, 1776." Ed. Norman Philbrick. Trumpets Sounding: Propaganda Plays of the American Revolution. New York: Arno P, 1976. 39-135. 
Meserve, Walter J. An Emerging Entertainment: The Drama of the American People to 1828. Bloomington: Indiana U P, 1977.

Moses, Montrose J. Representative Plays by American Playwrights 1765-1819. New York: Benjamin Blom, 1964.

Munford, Robert. "The Patriots." A Collection of Plays and Poems, by the Late Colonel Robert Munford. Ed. Chapel Hill: U of North Carolina, 2004. 2: 54-132.

Nathans, Heather. Early American Theatre from the Revolution to Thomas Jefferson. Into the Hands of the People. New York: Cambridge U P, 2003.

Paine, Thomas. "A Dialogue between General Wolfe and General Gage in a Wood near Boston." Ed. Philip. S. Foner. The Complete Writings of Thomas Paine. New York: Citadel P, 1945. 2:47-49.

Paine, Thomas. "A Dialogue between the Ghost of General Montgomery and an American Delegate." Ed. Philip. S. Foner. The Complete Writings of Thomas Paine. New York: Citadel P, 1945. 2:88-93.

Philbrick, Norman. Propaganda Plays of the American Revolution. New York: Arno P, 1976.

Quinn, Arthur H. A History of the American Drama from the Beginning to the Civil War. New York: Harper \& Brothers, 1923.

Rankin, Hugh F. The Theater in Colonial America. Chapel Hill: The U of North Carolina P, 1960.

Richardson, Gary A. American Drama from the Colonial Period through World War I: A Critical History. New York: Twayne Publishers, 1993.

Sewell, Jonathan. The Americans Roused in a Cure for the Spleen or Amusement for a Winter's Evening: Being the Substance of Conversation on the Times, over a Friendly Parson Bumper, a Country Justice Fillpot, an Inn-keeper Graveairs, a Deacon Trim, a Barber Brim, a Quaker Puff, a late Representative Taken in a short-hand by Sir Roger de Coverly. Tarrytown, N.Y.: W. Abbatt, 1922.

Shaffer, Jason. Performing Patriotism: National Identity in the Colonial and Revolutionary American Theater. Philadelphia: The $U$ of Pennsylvania P, 2017.

Shaffer, Jason. "Making an Excellent Die: Death, Mourning, and Patriotism in the Propaganda Plays of the American Revolution." Early American Literature 41.1 (2006): 1-27.

Stout, Harry S. The Divine Dramatist: George Whitefield and the Rise of Modern Evangelicalism, XVIII-XXIV. Grand Rapids: William B. Eerdmans Publishing Co., 1991. 
Teunnissen, John J. "Blockheadism and the Propaganda Plays of the American Revolution." Early American Literature 7(1972): 148162.

Tyler, Moses C. "The Party of the Loyalists in the American Revolution." American Historical Review 1(1895): 24-49.

Vickers, Vikki. My Pen and My Soul Have Ever Gone Together: Thomas Paine and the American Revolution. New York: Routledge, 2006.

\section{VIGOVCI PROTIV TORIJEVACA: RAZVOJ AMERIČKE DRAME}

Prezirni sarkazam i zajedljiva satira su svakako osećanja koja su obeležila američki ustavno-revolucionarni period. Približavajući se tako Američkoj revoluciji i borbi za nezavisnost, otkrivamo da je osećaj kolonista za smeh i smešno postajao sve izraženiji i sve spremniji da prepozna slabosti svog neprijatelja i da ih predstavi svetu kroz podrugljiv smeh satira. Brojne satire ovakvog karaktera se nisu iznenada pojavile. Njihov trag vodi do perioda mnogo godina pre izbijanja Rata za nezavisnost i do čuvene Bejkonove pobune 1676. godine. Ipak, ono što se ne može poreći je da približavanjem 1776. godine, satire postaju sve brojnije. Odmah nakon prvog ratnog udara satire počinju da se objavljuju u skoro svim dnevnim novinama $u$ kolonijama.

Američki dramatisti su uzeli aktivno učešće u borbi za nezavisnost. U početku potencijalna, a kasnije i izvesna revolucija naterala je dramatiste iz redova i patriota i lojalista da definišu sebe, svoje protivnike kao i prirodu samog sukoba na način koji ostaje intrigantan i moćan više od dve stotine godina kasnije.

Ključne reči: drama, pozorište, vigovci, torijevci, Američka revolucija 